\title{
PENERAPAN EDMODO PADA PEMBERIAN TES FORMATIF MAHASISWA PENDIDIKAN PROFESI GURU MATEMATIKA
}

\author{
Reni Dwi Susanti \\ Pendidikan Matematika, Universitas Muhammadiyah Malang \\ E-mail: renidwi@umm.ac.id
}

Received 26 June 2018; Received in revised form 17 September 2018; Accepted 21 September 2018

\begin{abstract}
This research aims to describe the application of formative tests on edmodo granting the student mathematics teacher education profession. This type of research is descriptive with qualitative approach. Data retrieval by way of observation, online tests and student response. The results of the research shows that with the application of the test for granting edmodo formative student PPG mathematics education is running very well and can be applied to the grant of formative tests. With Edmodo can easily see the results obtained by students, besides that with Edmodo can easily see the material that many students answered incorrectly and the settings for execution time can also be set. So that, with this time arrangement, the students will be able to manage the process of the question well. Edmodo also provides facilities to be able to randomize answers with questions in appearance, so that with the existence of the facility there is a possibility that between one student and another student gets the same problem but with a different number. The facility can also minimize students from working together. The implementation is also supported by several student responses. The results of student responses in the application of Edmodo for the provision of this formative test are very good.
\end{abstract}

Keywords: Edmodo; E-Learning; Formative Test.

\section{PENDAHULUAN}

Informasi dan teknologi

komunikasi (ICT) menjadi alat yang sangat diperlukan untuk belajar, khususnya multimedia komputer dan sumber daya internet (Sumintono, Wibowo, Dan, \& Tiawa, 2012). Adanya pemanfaatan multimedia komputer serta sumber daya internet dapat merubah sistem berkomunikasi maupun bersosialisasi, ini merupakan tantangan bagi seseorang untuk dapat memanfaatkan teknologi secara optimal. Pendidikan adalah salah satu bidang yang banyak memanfaatkan ICT, tepatnya menggunakan komputer dan sumber daya internet sebagai media pembelajaran.

Pemakaian media pembelajaran dalam proses belajar mengajar dapat membangkitkan minat dan keinginan yang baru, membangkitkan motivasi dan rangsangan kegiatan belajar, dan bahkan membawa pengaruh-pengaruh psikologis terhadap pebelajar
(Falahudin, 2014). Selain dalam proses pembelajaran dengan media juga dapat digunakan untuk kegiatan lain, misalnya adalah media e-learning yang memanfaatkan teknologi informasi dan internet. E-learning adalah pembelajaran jarak jauh (Distance Learning) yang memanfaatkan teknologi computer, jaringan komputer atau Internet secara online (Suriadhi \& Tastra, 2014). Pemanfaatan e-learning selain untuk kegiatan pembelajaran juga digunakan untuk pemberian tes.

$$
\text { Undang-undang Republik }
$$

Indonesia nomor 20 Tahun 2003 tentang Sistem Pendidikan Nasional yang menegaskan bahwa matematika merupakan salah satu mata pelajaran wajib. Fungsi mata pelajaran matematika salah satunya adalah melatih siswa untuk selalu berorientasi pada kebenaran dengan mengembangkan sikap logis, kritis, kreatif, objektif, rasional, cermat, disiplin, dan mampu bekerja sama 
secara efektif (Sujatmiko \& Aryuna, 2016). Oleh karena itu untuk mengembangkan sikap tersebut sering dilakukan dengan memberikan latihan soal. Pemberian latian soal atau tes formatif biasanya diadakannya pemberian tes formatif secara online atau melalui e-learning.

Pemberian tes formatif dengan cara online atau melalui e-learning banyak digunakan pada saat ini. Media e-learning yang dapat digunakan adalah edmodo. Edmodo adalah salah satu jenis media pembelajaran e-learning dalam bentuk website yang dapat digunakan untuk proses pembelajaran, penugasan maupun kuis yang dapat memuat berbagai media yang berupa gambar, animasi, teks, serta suara.

Penelitian yang dilakukan oleh Purnomo (2013) tentang keefektifan penilaian formatif terhadap hasil belajar matematika mahasiswa ditinjau dari motivasi belajar yang menyatakan bahwa pembelajaran berbasis penilaian formatif lebih efektif dibanding penilaian tradisional baik secara umum maupun untuk setiap kategori motivasi. Di sisi lain, hasil belajar matematika mahasiswa dengan kategori motivasi tinggi lebih baik daripada kategori motivasi rendah di setiap model pembelajaran berbasis penilaian yang diterapkan. Oleh karena itu adanya dengan adanya tes formatif melalui edmodo diharapkan dapat memotivasi dalam belajar mahasiswa dan dalam mengerjakan soal tes formatif.

Berdasarkan hasil observasi di lapangan pada September 2017, pendidikan Matematika Universitas Muhammadiyah Malang merupakan salah satu program studi yang dipercaya untuk menyelenggarakan program profesi guru (PPG). Mahasiswa Pendidikan Profesi Guru banyak mengalami kendala dan masalah ketika diberikan tes formatif melalui tulis.
Kendala dan masalah tersebut adalah terkait dengan pelaksanaan Ujian Tulis Nasional (UTN) PPG yang selalu dilakukan secara online, sehingga mahasiswa selalu menginginkan supaya pelaksanaan Tes Formatif juga menggunakan online. Dengan adanya tes online mahasiswa akan termotivasi untuk lebih giat karena dengan tes online waktu yang diberikan akan lebih jelas dan tersistem. Mahasiswa beranggapan bahwa motivasi tes formatif dengan tulis belum mempunyai tantangan yang banyak layaknya jika diadakan melalui e-learning. Dengan adanya penelitian ini diharapkan dapat menjadikan solusi untuk mengatasi permasalahan pemberian tes Formatif mahasiswa PPG yaitu dengan Penerapan Edmodo pada Pemberian Tes Formatif Mahasiswa Pendidikan Profesi Guru Matematika serta menganalisis keterlaksanaannya. Hal ini dikarenakan dengan penggunaan edmodo pada pelaksanaan tes tersebut akan dapat dikelola waktu pelaksanaannya dan nilai yang ada juga akan bisa langsung dapat diketahui oleh mahasiswa. Sehingga dengan adanya itu diharapkan untuk tes selanjutnya mahasiswa akan lebih giat dan dapat memperbaiki nilainya.

\section{METODE PENELITIAN}

Penelitian ini menggunakan jenis deskriptif dengan pendekatan kuantitatif. Subyek yang digunakan dalam penelitian ini adalah mahasiswa Pendidikan Profesi Guru (PPG) jurusan matematika Universitas Muhammadiyah Malang.Teknik pengumpulan data yang digunakan untuk mengumpulkan data keterlaksanaan kegiatan pembelajaran adalah dengan observasi, angket respon mahasiswa dan nilai tes.

Observasi dilakukan untuk mengetahui kesulitan apa saja yang dialami oleh mahasiswa selama 
kegiatan pendampingan serta mencatat atau menuliskan penemuan maupun kegiatan selama penelitian berlangsung. Sedangkan pemberian soal tes formatif secara Online guna melihat rata-rata persentase yang diperoleh mahasiswa yang didukung dengan adanya angket respon mahasiswa. Angket respon mahasiswa digunakan untuk melihat keefektifan penggunaan edmodo dalam pemberian tes formatif. Analisis data yang digunakan dalam penelitian ini yaitu dengan menelaah persentase seluruh hasil tes secara online, sedangkan untuk hasil angket dihitung rata-rata serta dikategorikan. Kemudian hasil tersebut dideskripsikan dengan didukung oleh hasil temuan-temuan saat observasi berlangsung dan dari respon mahasiswa terhadap penggunaan edmodo.

\section{HASIL PENELITIAN DAN PEMBAHASAN}

Penelitian ini dilakukan pada Maret-April 2018 pada mahasiswa PPG Pendidikan Matematika. Penelitian ini bertujuan untuk melihat keterlaksanaan penerapan Edmodo pada pemberian Tes Formatif mahasiswa Pendidikan Profesi Guru Pendidikan Matematika. Keterlaksanaan tersebut dilihat dari hasil tes formatif yang diperoleh mahasiswa dan didukung dengan adanya hasil respon mahasiswa serta temuan saat dilaksanakan observasi.

Dengan menggunakan edmodo dalam pemberian tes formatif dapat mempermudah pendidik dalam menganalisis hasil belajarnya serta dapat juga melihat evaluasi dari masingmasing soal yang digunakan. Edmodo mempermudah dosen untuk melakukan rekap hasil belajarnya, karena dengan edmodo akan dapat terlihat langsung skor yang diperoleh mahasiswa.

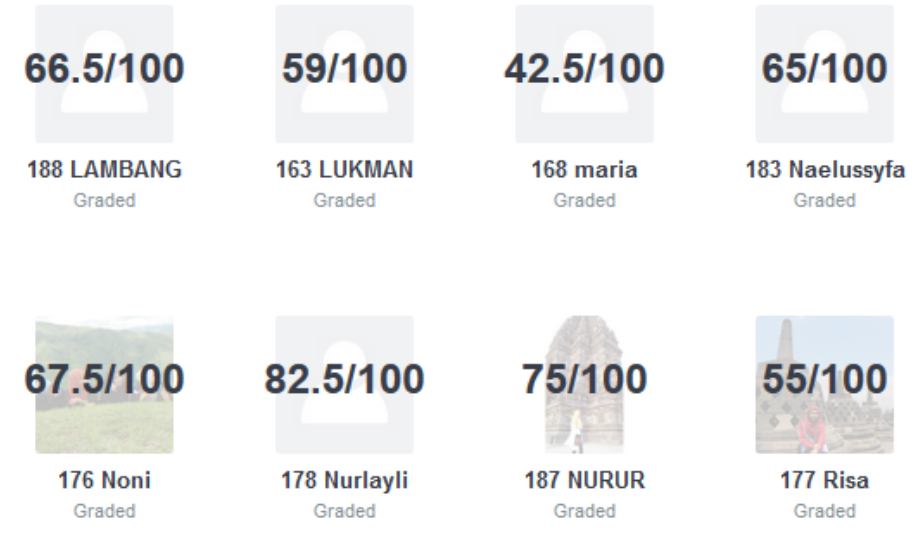

Gambar 1. Tampilan Skor pada Edmodo

Skor pada edmodo tersebut ditentukan pada awal penyusunan soal pada edmodo. Penentuan skor dapat disesuaikan tersendiri bergantung dari bobot soal yang diberikan serta menyesuaikan jumlah soal yang diberikan. Dalam edmodo itu sendiri untuk memunculkan equation dapat dengan menambahkan script [math]...[/math]. Tanpa menggunakan script tersebut equation dalam tampilan soal tidak akan bisa ditampilkan. Contoh penulisan dan hasil tampilannya adalah sebagai berikut : 
ISSN 2089-8703 (Print) Vol. 7, No. 2 (2018) 221-228

ISSN 2442-5419 (Online)

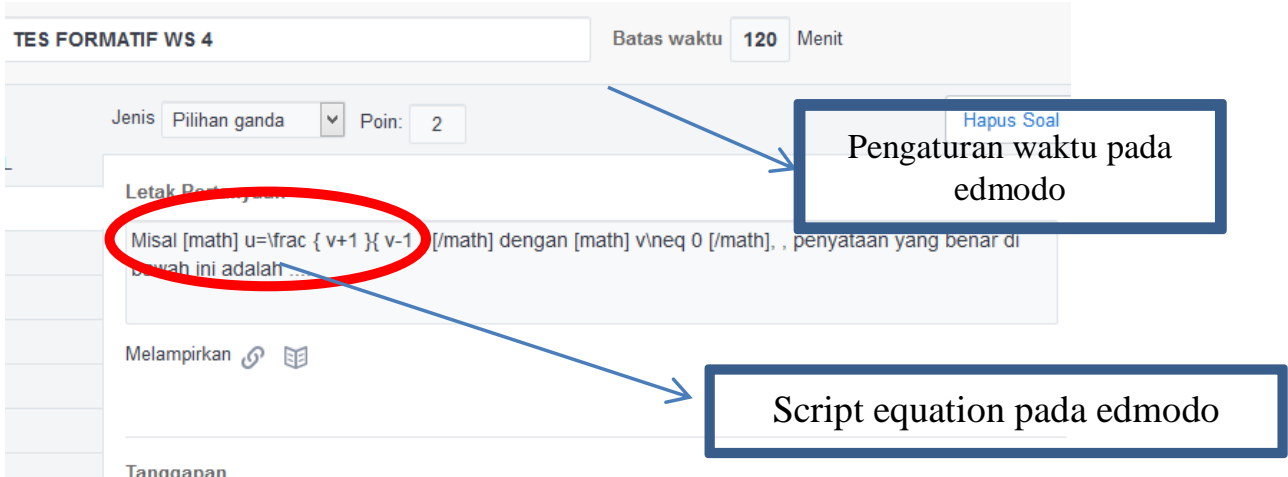

A [math] Ifrac $\{\mathrm{du}\} \mathrm{dv}\}$ Ineq 0, Iquad vineq $1[/ \mathrm{math}]$

Melampirkan of 通

Gambar 2. Penulisan script equation pada Edmodo

Gambar 2 adalah salah satu contoh penulisan simbol dan angka dalam equation pada edmodo. Penulisan script tersebut dibantu aplikasi pada google chrome yaitu Daum Equation

$$
\begin{aligned}
& \text { Pertanyaan } 1 \\
& \text { Misal } u=\frac{v+1}{v-1} \text { dengan } \\
& \hline \text { A } \frac{d u}{d v} \neq 0, \quad v \neq 1 \\
& \text { B } \frac{d u}{d v}<0, \quad v \neq 1 \\
& \hline \text { C } \frac{d u}{d v}>0, \quad v \neq 1
\end{aligned}
$$$$
\text { Misal } u=\frac{v+1}{v-1} \text { dengan } v \neq 0 \text {, penyataan yang benar di bawah ini adalah ... }
$$

Editor. Dimana dalam aplikasi tersebut dapat menuliskan equation pada matematika dan selanjutnya dapat copy dan paste pada editor edmodo dengan menambahkan script [math] ... [/math].

Gambar 3. Tampilan equation pada soal

Terdapat pula dalam edmodo analisis untuk soal-soal yang banyak dikerjakan mahasiswa dengan benar atau salah. Sehingga dengan adanya itu dapat terlihat soal pada bidang apa yang banyak dikerjakan salah. Contoh tampilannya adalah sebagai berikut :

\section{4 | AKSIOMA}

Jurnal Pendidikan Matematika FKIP Univ. Muhammadiyah Metro 
ISSN 2089-8703 (Print) Vol. 7, No. 2 (2018) 221-228

ISSN 2442-5419 (Online)

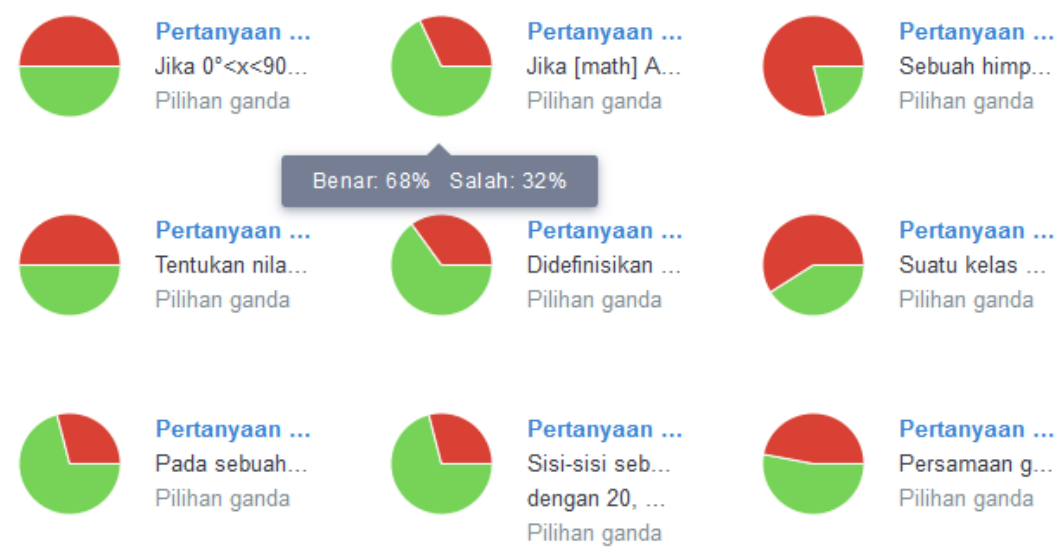

Gambar 4. Tampilan hasil analisis per soal berdasarkan jawaban benar dan salah

Gambar tersebut menunjukkan hasil analisis untuk tiap soal, terdapat persentase untuk setiap soal yang dijawab benar dan dijawab salah. Berdasarkan analisis tersebut didapatkan hasil bahwa :

Tabel 1. Hasil Analisis Penguasaan Soal Berdasarkan bidang matematika Tes formatif 1

$$
\text { Materi Jumlah Soal Respon Benar (\%) Respon Salah (\%) }
$$

\begin{tabular}{lccc}
\hline Bilangan & 6 & 51 & 49 \\
\hline Aljabar & 8 & 60 & 40 \\
\hline Kombinatorika & 5 & 41 & 59 \\
\hline Geometri & 6 & 45 & 55 \\
\hline Trigonometri & 3 & 52 & 48 \\
\hline Logika & 2 & 69 & 31 \\
\hline Kalkulus & 10 & 46 & 54 \\
\hline Rata-rata & 40 & 52 & 48 \\
\hline
\end{tabular}

Dengan adanya persentase soal yang dijawab benar dan salah maka dapat dilakukan evaluasi untuk soal yang diberikan. Dalam hal ini soal yang banyak dikerjakan salah oleh mahasiswa adalah pada bidang Kombinatorik, Geometri dan Kalkulus. Bidang kombinatorik banyak dilakukan kesalahan karena mahasiswa kurang dapat menginterpretasikan soal sehingga dalam perhitungan dan penggunaan rumus juga mengalami kesalahan. Pada materi geometri banyak dilakukan kesalahan mahasiswa yaitu dalam hal permisalan atau interpretasi soal pada gambar. Selain itu mahasiswa juga banyak melakukan kesalahan ketika melakukan perhitungan. Selain kombinatorik dan geometri adapula materi pada kalkulus.

Kalkulus merupakan cabang ilmu dalam matematika yang membahas beberapa materi, misalnya adalah limit, turunan, integral, vektor dan matriks. Jawaban salah pada bidang kalkulus yang dilakukan mahasiswa sebagian besar adalah pada materi limit dan vektor. Pada kedua materi ini mahasiswa tidak bisa mengoperasikan soal dengan menggunakan ruang vektor. 
Setelah melakukan analisis untuk setiap soal yang bernilai benar dan salah serta analisis untuk materi apa saja mahasiswa yang mengalami kesalahan selanjutnya adalah hasil belajar. Hasil belajar mahasiswa dilihat dari rata-rata persentase keseluruhan untuk skor yang diperoleh. Hasil belajar dilihat dari perolehan rata-rata persentase untuk setiap tes formatif. Adapun persentase hasil tes formatifnya adalah sebagai berikut.

Tabel 2. Hasil rata-rata persentase hasil tes formatif

\begin{tabular}{lcc}
\hline No & Tes & Rata-rata Persentase (\%) \\
\hline 1 & Tes formatif 1 & 49 \\
\hline 2 & Tes formatif 2 & 54 \\
\hline 3 & Tes formatif 3 & 59 \\
\hline 4 & Tes formatif 4 & 62 \\
\hline
\end{tabular}

Tabel 2 menunjukkan bahwa rata-rata persentase untuk masingmasing hasil tes formatif. Jumlah soal dan waktu yang diberikan untuk setiap tes formatif yaitu berjumlah 40 soal dengan waktu 120 menit. Soal yang diberikan terdiri dari 40 soal matematika yang terdiri dari berbagai macam bidang matematika. Pemberian tes formatif dilakukan setiap dua minggu satu kali. Distribusi soal yang diberikan juga bervariasi dan berbeda.

Rata-rata hasil untuk setiap tes formatif tersebut dapat dilihat secara langsung berada dalam gambaran Quiz. Tampilan hasil rata-rata perolehannya adalah sebagai berikut.

\section{TES FORMATIF 2 \\ Gambaran Quiz Semua penyerahan}

\section{Nilai rata-rata $49 \%$}

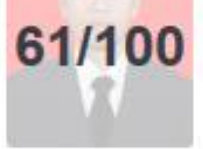

\section{$47 / 100$}

Gambar 5. Contoh tampilan rata-rata persentase hasil yang diperoleh

Hal ini juga di dukung oleh hasil respon mahasiswa terkait penggunaan edmodo dalam pemberian tes formatif. Hasil respon mahasiswa tersebut adalah sebagai

Tabel 3. Hasil persentase respon mahasiswa dengan penggunaan edmodo

\begin{tabular}{clcc}
\hline No & \multicolumn{1}{c}{ Aspek } & Persentase $(\%)$ & Kategori \\
\hline 1 & Kemudahan dalam penggunaan edmodo & 88,65 & Sangat Baik \\
\hline 2 & $\begin{array}{l}\text { Kejelasan dalam tampilan symbol dan angka } \\
\text { dalam matematika }\end{array}$ & 87,55 & Sangat Baik \\
\hline 3 & $\begin{array}{l}\text { Tingkat fungsionalitas edmodo untuk } \\
\text { meningkatkan minat mahasiswa }\end{array}$ & 86,88 & Sangat Baik \\
\hline
\end{tabular}




\begin{tabular}{clccc}
\hline 4 & $\begin{array}{l}\text { Tingkat fungsionalitas edmodo untuk } \\
\text { meningkatkan motivasi mahasiswa dalam } \\
\text { mengerjakan soal }\end{array}$ & 84,74 & Sangat Baik \\
\hline 5 & $\begin{array}{l}\text { Bisa mengkontrol alokasi waktu dengan } \\
\text { jumlah soal yang dikerjakan }\end{array}$ & 81,25 & Baik \\
\hline & & 85,81 & Sangat Baik \\
\hline
\end{tabular}

Berdasarkan data respon mahasiswa tersebut dapat dikatakan bahwa penggunaan edmodo dalam pemberian tes formatif dapat dikatakan sangat baik. Kategori sangat baik ini yaitu dengan penerapan edmodo mahasiswa menjadi terlatih untuk mengerjakan yang menyerupai Ujian Tulis Nasional (UTN) PPG yang diberikan oleh pemerintah, mahasiswa lebih bersemangat dalam mengerjakan soal, mahasiswa menjadi termotivasi untuk segera menyelesaikan karena dengan edmodo digunakan batasan waktu, dengan edmodo dapat langsung mengetahui hasil akhir dari apa yang dikerjakan serta dapat dilakukan dimanapun dan kapanpun. Penelitian yang sejalan dengan penggunaan edmodo sebagai media pembelajaran adalah penelitian yang menunjukkan bahwa dengan edmodo dapat secara efektif untuk pengembangan pedagogis serta tetap dengan dasar teoritis pembelajaran (Kong, S. C., 2014).

\section{KESIMPULAN DAN SARAN}

Berdasarkan hasil penelitian dan pembahasan tersebut dapat diambil kesimpulan bahwa dengan penerapan edmodo untuk pemberian tes formatif mahasiswa PPG Pendidikan Matematika adalah berjalan dengan baik dan dapat diterapkan untuk pemberian tes formatif. Dengan edmodo dapat dengan mudah untuk melihat hasil yang diperoleh oleh mahasiswa, selain itu dengan edmodo dapat dengan mudah melihat materi yang banyak dijawab salah oleh mahasiswa dan pengaturan untuk waktu pelaksanaan juga dapat di atur. Sehingga dengan adanya pengaturan waktu tersebut mahasiswa akan dapat mengelola proses pengerjaan soal dengan baik pula. Edmodo juga memberikan fasilitas untuk dapat mengacak jawaban dengan soal dalam tampilannya, sehingga dengan adanya fasilitas itu terdapat kemungkinan bahwa antara mahasiswa satu dengan mahasiswa yang lainnya mendapatkan soal yang sama namun dengan nomor yang berbeda. Fasilitas tersebut juga dapat meminimalisir mahasiswa untuk bekerja sama. Pelaksanaan tersebut juga didukung dengan beberapa respon siswa.. Hasil respon mahasiswa dalam penerapan edmodo untuk pemberian tes formatif ini adalah tergolong sangat baik.

Saran yang bisa disampaikan untuk pelaksanaan tes formatif dengan menggunakan edmodo bisa diberikan untuk semua program studi. Selain itu penggunaan edmodo dapat juga digunakan untuk media e-learning dalam segala mata pelajaran ataupun mata kuliah yang lain. Penggunaan edmodo untuk pembelajaran matematika untuk bisa dikembangkan lagi dalam penggunaan Microsoft equation di browser yang lain, sehingga tidak terbatas pada google chrome.

\section{DAFTAR PUSTAKA}

Falahudin Widyaiswara Balai Diklat Keagamaan Jakarta, I., Rawa Kuning Pulo Gebang Cagung, J., \& Timur, J. (2014). Pemanfaatan Media dalam Pembelajaran. Edisi, 1(4), 104-117. 
ISSN 2089-8703 (Print) Vol. 7, No. 2 (2018) 221-228

ISSN 2442-5419 (Online)

Kong, S. C., \& S. Y. (2014). The Impact of a Principle-based Pedagogical Design on Inquirybased Learning in a Seamless Learning Environment in Hong Kong. Educational Technology \& Society, 2(14), 127-141.

Purnomo, Y. W. (2013). Keefektifan penilaian formatif terhadap hasil belajar matematika mahasiswa ditinjau dari motivsi belajar. Prosiding Seminar Nasional Matematika Dan Pendidikan Matematika, (November), 649656.

Sujatmiko, P., \& Aryuna, D. R. (2016). PENINGKATAN KOMPETENSI GURU MATEMATIKA SMP, (November), 848-860.

Sumintono, B., Wibowo, S. A., Dan, N. M., \& Tiawa, D. H. (2012). Pengaruh penggunaan media. Jurnal Pengajaran MIPA, 12(7), 122-131. Retrieved from https://umexpert.um.edu.my/file/p ublication/00013268_112478.pdf

Suriadhi, G., \& Tastra, I. D. K. (2014). Pelajaran IPA Kelas VIII DI SMP Negeri 2 Singaraja. Edutech, 2(1). 